\title{
Optimization Of Coal Production Based On Operational Cost Efficiency At PT. Tambang Bukit Tambi
}

\author{
Nur Hanif, Hidayatullah Sidiq, Novandri Kusuma Wardana \\ \{ nurhanif139@gmail.com, hidatullahsidiq@itny.ac.id,novandri.kusuma@itny.ac.id \} \\ Department of Mining Engineering Faculty of Mineral Technology Yogyakarta National \\ Institute of Technology Yogyakarta, Indonesia
}

\begin{abstract}
PT. Tambang Bukit Tambi is one of the private companies engaged in coal mining located in Padang Kelapo Village, Moro Sebu Ulu District, Batang Hari Regency, Jambi Province. In coal mining activities using 2 fleets of excavators Komatsu PC400LC8 and Dump Truck Hino FM 260 JD, Nissan CWM 330 PS and Nissan CWA 260 X. Research methods used to obtain data - data is quantitative method. The company's production target of 50,000 tons/month was not reached. The combination of tools in fleet 1 has a match factor value of 0.78 while fleet 2 is 0.82 . Operating costs incurred today amount to $\mathrm{Rp} 27,047 / \mathrm{bcm}$. Fuel usage can be optimized using Mixed Integer Linear Programming (MILP) method, on fleet 1 by $27 \%$ and fleet 2 by $36 \%$. In this study, effective working time improvement, swing angle and cycle time Dump Truck were conducted. Thus, after the improvement, there is no excess financing of operational costs in coal mining activities.
\end{abstract}

Keywords: Production, Cost, MILP

\section{Introduction}

PT. Tambang Bukit Tambi is a company engaged in the coal mining business located in batang hari district. Mining methods implemented by PT. Tambang Bukit Tambi is a surface mining method. In conducting coal mining activities require mechanical equipment and planning production activities well to achieve production targets that have been determined by the company. The number of tools used depends on the production schedule along with basic assumptions about productivity [2]. In this mining process, there is often a waiting time for the load digging equipment resulting in the mismatch of work of the load digging equipment and hauling equipment. The mismatch of work of the tool causes the occurrence of over-financing [4]. Then it is necessary to optimize the production of loading and hauling equipment so that there is no excess financing and production reaches the planned target. 


\section{Research Method}

Research methods applied to obtain data - data is a quantitative method and stages in this preparation is collecting references related to research, conducting introduction and field to know the potential problems that will occur, then conducting primary data retrieval consists of data cycle time excavator load PC400LC-8, cycle time dump truck hauling Hino FM 260 JD, Nissan CWM 330 PS and Nissan CWA 260 X, loading pattern, fill factor, swell factor, number of operating tools, amount of bulk filling, actual bottleneck time on the tool, fuel consumption data and field documentation. While the secondary data consists of geological data of research areas, rainy day data, maps of regional reach, specifications of excavator loading equipment PC400LC-8, specifications of dump truck hauling Hino FM 260 JD, Nissan CWM 330 PS and Nissan CWA 260 X, data maintenance heavy equipment, fuel cost data, filters (oil, fuel and air), lubricants and operator salaries. Then the processing and analysis of data in accordance with its usefulness until conclusions and suggestions are obtained. In this study, the optimization of fuel usage using the Mixed Integer Linear Programming (MILP) method was carried out. MILP method is a method that optimizes route selection and will reduce the consumption of materials and transportation with the aim of achieving production targets [1].

\section{Result}

For coal mining in PT. Bukit Tambi mine has 2 fleets that use a combination of 1 unit of excavator PC400LC-8 as a means of digging and 7 units of dump truck nissan CWM 330 PS, 2 units of hino FM 260 JD dump truck and 1 unit of dump truck nissan CWA $260 \mathrm{X}$ in each fleet. In addition to the main mechanical tools above, there are several mechanical tools support to support the main mechanical equipment, namely water trucks, bulldozers, motor graders and solar tanks.

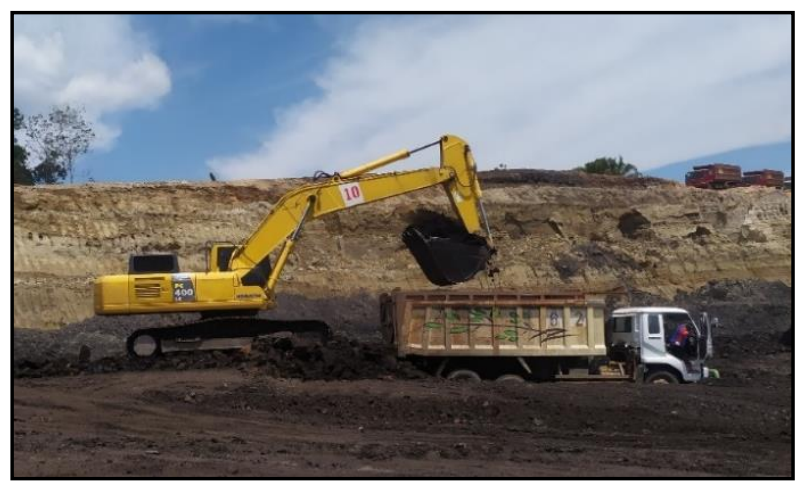

Fig. 1Mining at PT. Tambang Bukit Tambi

In addition to the main mechanical tools above, there are several mechanical tools support to support the main mechanical equipment, namely water trucks, bulldozers, motor graders and solar tanks.

Table 1 Tools Cycle Time 


\begin{tabular}{lll}
\hline \multirow{2}{*}{ Tools } & \multicolumn{2}{l}{ Cycle Time } \\
\cline { 2 - 3 } & Fleet 1 (seconds) & Fleet 2 (seconds) \\
\hline Excavator & 21,81 & 22,89 \\
\hline Dump Truck & 2.767 & 2.749 \\
\hline
\end{tabular}

Table 2 Availability Of Tools

\begin{tabular}{lllll}
\hline \multirow{2}{*}{ Description } & \multicolumn{2}{l}{ Excavator } & \multicolumn{2}{c}{ Dump Truck } \\
\cline { 2 - 5 } & Fleet 1 & Fleet 2 & Fleet 1 & Fleet 2 \\
\hline MA (\%) & 88,18 & 91,53 & 88,07 & 89,02 \\
\hline PA (\%) & 91,85 & 93,60 & 92,07 & 92,46 \\
\hline UA (\%) & 54,24 & 56,04 & 57,42 & 58,56 \\
\hline EU (\%) & 88,07 & 52,45 & 52,87 & 54,14 \\
\hline
\end{tabular}

The availability of tools is a very important factor in scheduling a tool [3]. It can be known based on the workings of the tool [5] ma and PA values are good while the value of UA and EU is not good because $<75 \%$ UA value and $<65 \%$ EU value, this is because of the time obstacles that can not be avoided rain \& slippery. There are several working days not used to operate, resulting in coal mining operations are not maximized.

Table 3 Production Of Loading And Hauling Equipment

\begin{tabular}{llll}
\hline Description & Tools & Production (ton/month) & MF \\
\hline Fleet 1 & 1 Excavator & $22.377,09$ & 0,79 \\
\cline { 2 - 3 } & 10 Dump Truck & $19.836,07$ & \\
\hline Fleet 2 & 1 Excavator & $24.524,44$ & \multirow{2}{*}{0,82} \\
\cline { 2 - 3 } & 10 Dump Truck & $21.165,52$ & \\
\hline
\end{tabular}

From the calculation of the data obtained, the operational costs of Komatsu PC400LC- 8 excavator and dump truck Nissan CWM 330 PS, Hino 500 FM 260 JD, Nissan CWA 260 X in table 4 .

Table 4 Calculation Of Mechanical Equipment Hourly Cost

Description Tools




\begin{tabular}{|c|c|c|c|c|}
\hline (Hours) & $\begin{array}{l}\text { Excavator } \\
\text { Komatsu } \\
\text { PC400LC-8 }\end{array}$ & $\begin{array}{l}\text { Nissan CWM } \\
330 \text { PS }\end{array}$ & $\begin{array}{l}\text { Nissan } \\
\text { CWA } 260 X\end{array}$ & $\begin{array}{l}\text { Hino } 500 \mathrm{FM} \\
260 \mathrm{JD}\end{array}$ \\
\hline Fuel & $\operatorname{Rp} 466.140$ & Rp 264.192 & Rp 163.581 & Rp 166.899 \\
\hline $\begin{array}{l}\text { Oil and } \\
\text { grase }\end{array}$ & $\mathrm{Rp} \quad 4.925$ & Rp $\quad 3.723$ & $\mathrm{Rp} \quad 4.049$ & 4.091 \\
\hline Filter & $\mathrm{Rp} \quad 7.500$ & $\mathrm{Rp} \quad 1.952$ & $\mathrm{Rp} \quad 2.172$ & $\mathrm{Rp} \quad 1.780$ \\
\hline Operator fee & $\mathrm{Rp} 25.000$ & $\mathrm{Rp} \quad 25.000$ & Rp 25.000 & $\mathrm{Rp} \quad 25.000$ \\
\hline Total & Rp 513.565 & Rp 294.867 & Rp 194.803 & Rp 197.770 \\
\hline
\end{tabular}

Based on the operational cost of each excavator Komatsu PC400LC-8 and dump truck Nissan CWM 330 PS, Hino 500 FM 260 JD, Nissan CWA 260 X that has been obtained, the amount of operational costs of loading and hauling equipment is Rp 27,047/bcm

Table 5 Operational Costs Of Loading And Hauling Equipment

\begin{tabular}{|c|c|c|c|c|}
\hline Tools & $\begin{array}{l}\text { Effective } \\
\text { Working } \\
\text { Hours }\end{array}$ & $\begin{array}{l}\text { Operating } \\
\text { Costs/hours }\end{array}$ & Units & $\begin{array}{l}\text { Total Operating } \\
\text { Costs }\end{array}$ \\
\hline Excavator & 136,79 & Rp 513.565 & 1 & $\mathrm{Rp} \quad 70.249 .588$ \\
\hline Nissan CWM & 145,17 & Rp 294.867 & 7 & Rp 299.643.452 \\
\hline Hino & 145,17 & Rp 197.770 & 2 & Rp 57.421 .204 \\
\hline Nissan CWA & 145,17 & Rp 194.803 & 1 & Rp 28.279 .811 \\
\hline Excavator & 144,00 & $\operatorname{Rp} 513.565$ & 1 & Rp 73.955 .816 \\
\hline Nissan CWM & 148,65 & Rp 294.867 & 7 & Rp 306.833.283 \\
\hline Hino & 148,65 & Rp 197.770 & 2 & Rp 58.799 .004 \\
\hline Nissan CWA & 148,65 & Rp 194.803 & 1 & Rp 28.958 .375 \\
\hline \multicolumn{4}{|c|}{ Total Operating Costs } & Rp 924.140 .535 \\
\hline \multicolumn{5}{|l|}{$\begin{array}{l}\text { Operational c } \\
\text { equipment for } n\end{array}$} \\
\hline \multicolumn{5}{|l|}{1 BCM Coal } \\
\hline \multicolumn{5}{|c|}{$=\frac{\text { total cost of production }}{\text { coal production per month }}$} \\
\hline \multicolumn{5}{|c|}{$=\frac{\text { Rp 924.140.535 }}{34.168}$} \\
\hline
\end{tabular}


Production target planned by PT. The Bukit Tambi mine in March 2020 was 50,000 tons/month. While mining production calculation results for 2 units of excavator Komatsu PC400LC-8 and 14 dump trucks Nissan CWM 330 PS, 4 units Hino 500 FM 260 JD, 2 units Nissan CWA 260 $\mathrm{X}$ achieved today amounted to 41,002 tons/month. So there is still a shortfall of 8,998 tons/month. The shortage is caused by low effective working time, swing angle excavator $>90^{\circ}$ and cycle time dump truck too long that the company has set for 40 minutes for hauling. Therefore, improvements are made so that coal mining production targets can be achieved.

Table 6 Availability Of Tools

\begin{tabular}{lcccc}
\hline Keterangan & \multicolumn{2}{c}{ Excavator } & \multicolumn{2}{c}{ Dump Truck } \\
\cline { 2 - 5 } & Fleet 1 & Fleet 2 & Fleet 1 & Fleet 2 \\
\hline MA (\%) & 91,17 & 93,57 & 90,73 & 91,35 \\
\hline PA (\%) & 91,85 & 93,60 & 92,07 & 92,46 \\
\hline UA (\%) & 75,05 & 56,04 & 76,15 & 76,31 \\
\hline EU (\%) & 68,93 & 52,45 & 70,12 & 70,55 \\
\hline
\end{tabular}

After the improvement of working time, the value of tool availability increases. In addition to improving effective working time, swing angle also affects production. Swing angle is the angle of rotation of the digger and loading when the tool swings both in the content state and in an empty state. In actual conditions in the field the average swing angle on fleet 1 is $106^{\circ}$ the release time is 21,81 seconds and the fleet 2 is $128^{\circ}$ the release time is 22,89 seconds. Theoretically cycle time angle $45^{\circ}-90^{\circ}$ is 16 - 19 seconds [6]. Based on the results of calculations after repairs to fleet 1 obtained an angle of $76^{\circ}$ circulation time of 18,18 seconds and a fleet 2 angle of $88^{\circ}$ circulation time of 17,80 seconds. Thus the circulation time can be reduced and can increase the productivity of the load digging tool. With the increase in effective working time, swing angle repair and repair of cycle dump truck production of loading and hauling equipment experienced an increase, for Excavator Komatsu PC400LC-8 which is 46.901,54 tons/month increased to 111.701,37 tons/month while the Nissan CWM 330 PS hauling, Hino 500 FM 260 JD and Nissan CWA 260 X increased from 41.001,58 tons/month to $97.893,85$ tons/month, resulting in PT. Tambang Bukit Tambi desired production target. can be achieved. The increase in production also affected the value of match factor, the value of match factor fleet 10,79 to 0,89 while fleet 20,83 to 0,87 . The increase in the value of match factor and production will affect the production losses experienced by the company.

Table 7 Loss Of Production Of Loading And Hauling Equipment

\begin{tabular}{lcccc}
\hline Description & \multicolumn{2}{c}{ Before } & \multicolumn{2}{c}{ After } \\
\cline { 2 - 5 } & Fleet 1 & Fleet 2 & Fleet 1 & Fleet 2 \\
\hline $\begin{array}{l}\text { Production losses } \\
(\text { BCM })\end{array}$ & 22,46 & 23,27 & 24,20 & 38,82 \\
\hline
\end{tabular}




\begin{tabular}{|c|c|c|c|c|}
\hline Time (hours) & 0,16 & 0,16 & 0,10 & 0,15 \\
\hline Fuel & Rp 76.794 & Rp 76.428 & Rp 48.200 & Rp 71.976 \\
\hline Oil and grase & Rp 2.459 & Rp 2.447 & $\mathrm{Rp} 1.543$ & Rp 2.304 \\
\hline Filter & $\mathrm{Rp} 1.236$ & Rp 1.230 & $\mathrm{Rp} \quad 776$ & $\mathrm{Rp} \quad 1.158$ \\
\hline Operator fee & $\mathrm{Rp} \quad 4.119$ & Rp 4.099 & $\mathrm{Rp} \quad 2.585$ & Rp 3.860 \\
\hline \multirow[t]{2}{*}{ Total Cost } & Rp 84.607 & Rp 84.203 & $\operatorname{Rp} 61.107$ & Rp 53.104 \\
\hline & \multicolumn{2}{|c|}{ Rp 168.811/hours } & \multicolumn{2}{|c|}{ Rp 132.403 /hours } \\
\hline
\end{tabular}

Production losses are caused by the waiting time of loading and hauling equipment in operation, the longer the waiting time or match factor is not close to 1 then the loss of production will be greater [8]. Production losses are calculated, namely fuel costs, oil and grease costs, filter costs and operator costs.

Based on the results of the calculation of the improvement of the circulation time of the hauling equipment, namely 2,282, 2,025, 1,825 and 1,665 seconds, the match factor increased. Thus, the most optimal result is a match factor that is close to the value of 1 can be seen in figure 2 .

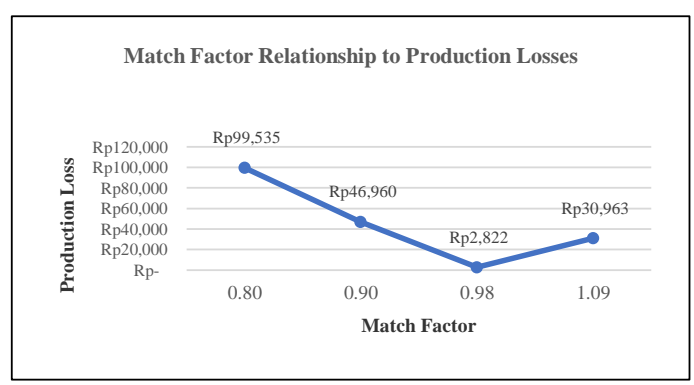

Fig 2 The relationship of production losses to match factor

Based on the operating costs of each excavator PC400LC-8 and dump truck Nissan CWM 330 PS, Hino 500 FM 260 JD and Nissan CWA $260 \mathrm{X}$ that have been obtained, the amount of operational costs of the loading and hauling equipment Rp 14,981 / bcm. Details of operational costs after repair can be found in Table 8 .

Table 8 Loading And Hauling Equipment Operating Costs After Repair

\begin{tabular}{llllll}
\hline Tools & $\begin{array}{l}\text { Effective } \\
\text { Working } \\
\text { Hours }\end{array}$ & $\begin{array}{l}\text { Operating } \\
\text { Costs/hours }\end{array}$ & Units & $\begin{array}{l}\text { Total } \\
\text { Costs }\end{array}$ \\
& Excavator & 189,27 & Rp 513.565 & 1 & Rp 97.203 .195 \\
\hline
\end{tabular}




\begin{tabular}{|c|c|c|c|c|}
\hline Nissan CWM & 192,52 & Rp 294.867 & 7 & Rp 397.376.991 \\
\hline Hino & 192,52 & Rp 197.770 & 2 & $\mathrm{Rp} \quad 76.150 .055$ \\
\hline Nissan CWA & 192,52 & Rp 194.803 & 1 & Rp 37.503 .728 \\
\hline Excavator & 194,07 & Rp 513.565 & 1 & Rp 99.668 .307 \\
\hline Nissan CWM & 193,72 & Rp 294.867 & 7 & Rp 399.853.871 \\
\hline Hino & 193,72 & Rp 197.770 & 2 & Rp 76.624 .704 \\
\hline Nissan CWA & 193,72 & Rp 194.803 & 1 & Rp 37.737 .491 \\
\hline \multicolumn{4}{|c|}{ Total Operating Costs } & Rp 1.222.118.343 \\
\hline $\begin{array}{l}\text { Operational } \\
\text { equipment fo }\end{array}$ & $\begin{array}{l}\text { ts of } \\
\text { ning }\end{array}$ & ng and & ling & Rp 14.98 \\
\hline
\end{tabular}

\section{BCM Coal}

$$
\begin{gathered}
=\frac{\text { total cost of production }}{\text { coal production per month }} \\
=\frac{\text { Rp 1.222.118.342 }}{81.578}
\end{gathered}
$$

In this study after the improvement of work efficiency and technical work such as swing angle excavator repair and cycle time dump truck repair, operational cost to mine 1 BCM coal decreased from Rp 27,047/bcm to

Rp 14,981/bcm. The amount of cost depends on how long the device is operating [7]. Therefore, the amount of productivity of the hourly equipment will affect the production of the month and the costs that must be incurred. The use of tool fuel can be optimized using the Mixed Integer Linear Programming (MILP) method. Based on the calculation using mixed integer linear programming (MILP) method, the author compares the results of the recommendation calculation with the actual field. This recommendation is derived from calculations that previously collected data on hauling speed, load and uncharged haul distances as well as the duration of shifts in hours. The author makes recommendations based on transport speed of $35 \mathrm{~km} / \mathrm{h}, 40 \mathrm{~km} / \mathrm{h}$ and $45 \mathrm{~km} / \mathrm{h}$ (Figure 3.). Then obtained recommendations with a speed of $40 \mathrm{~km} / \mathrm{h}$ based on the time of distribution of transportation, equipment conditions and K3 (occupational health and safety).

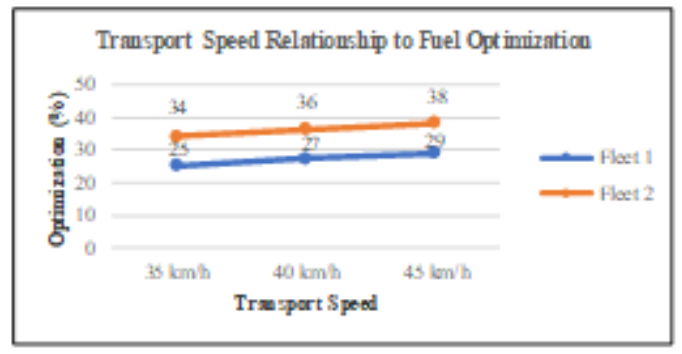


Fig 3 Transport Speed Relationship with Fuel Optimization

In fleet 1 of fuel issued 3.30 liters/ton can be minimized to 2.72 liters/ton with optimization of $27 \%$ while in fleet 2 of the fuel issued 3.26 liters/ton can be minimized to 2.36 liters/ton with optimization of $36 \%$.

\section{Conclusion}

Based on the results of research conducted at PT. Bukit Tambi mine can be concluded as follows: Actual production of Excavator Komatsu PC400LC-8 loading equipment is 46.901,54 tons/month, after repair of working hours and swing angle of excavator production to $111.701,37$ tons/month. While the actual production of Dump Truck Nissan CWM 330 PS, Hino 500 FM $260 \mathrm{JD}$ and Nissan CWA $260 \mathrm{X}$ is actually 41.001,58 tons/month, after improvements in working hours and production cycle time to $97.893,85$ tons/month. The match factor value in fleet 1 is 0,79 while fleet 2 is 0,83 with a total cost loss of Rp 168.811 /hour. After the improvement of the value of match factor in fleet 1 is 0,89 while fleet 2 is 0,87 with a total cost loss of Rp 132.403 /hour. The use of fuel in fleet 1 can be optimized from 3,75 liters/ton to 2,72 liters/ton by $27 \%$ while in fleet 2 can be optimized from 3,70 liters/ton to 2,36 liters/ton by $36 \%$. This optimization uses the Mixed Integer Linear Programming (MILP) method. The operational cost of loading and transportation equipment is currently Rp 27.047 /bcm while after repairing working hours, swing angle excavator and cycle time dump truck, operational costs become more efficient at Rp $14.981 / \mathrm{bcm}$. From the research in the field and the description and discussion conducted earlier, the author gives suggestions, among others: There needs to be supervision from the supervisor in charge of the set working time to prevent obstacles that occur during work. There needs to be supervision of the match factor of load digging equipment and hauling equipment so that there is no waiting time on the loading and hauling equipment that will result in production losses. Based on observations in the field and also data repair hours, it was obtained that there are several loading and hauling equipment that often suffer damage so as to reduce the reach of production. Therefore, it is necessary to periodically take care of the tools used in accordance with the time so that the damage that occurs to the tool is getting smaller.Routine evaluation for each operator in order to obtain an ideal position in the loading of both digging and hauling equipment.

\section{Acknowledgment}

Gratitude to all parties who have provided assistance and good guidance to field supervisors at PT. Tambang Bukit Tambi, supervisors at the Yogyakarta National Institute of Technology campus, mining zestien comrades, HMTA ITNY family until finally this research and scientific work can be completed. 


\section{References}

[1.] Bajany, D. M., Xia, X. and Zhang, L. 2017, A MILP model for truck-shovel scheduling to minimize fuel consumption, Energy Procedia, University of Pretoria

[2.] Bargawa, W. S, 2018, Perencanaan Tambang, Kilau Book, Yogyakarta

[3.] Indonesianto, Y., 2018, Pemindahan Tanah Mekanis, Jurusan Teknik Pertambangan, Sekolah Tinggi Teknologi Nasional, Yogyakarta.

[4.] Istiqamah, D. A, Gusman, M., 2019, Kajian Teknis Optimasi Produksi Alat Gali Muat Dan Alat Angkut Pada Kegiatan Pengupasan Overburden Berdasarkan Efisiensi Biaya Operasional Di Pit Barat PT. Allied Indo Coal Jaya Kota Sawahlunto, Jurnal Bina Tambang, vol 5, hal 61-73.

[5.] Keputusan Menteri Energi dan Sumber Daya Mineral Republik Indonesia Nomor 1827K/30/MEM/ 2018 tentang Pedoman Pelaksanaan Kaidah Teknik Pertambangan Yang Baik

[6.] Komatsu. 2009. Komatsu: Specification \& Application Handbook Edition 30, Japan.

[7.] Mirza, M., 2019, Analisis Pengaruh Geometri Jalan Terhadap Fuel Ratio Dan Biaya Angkut Dump Truck HINO FM 260 JD Dalam Kegiatan Penambangan Di Front Tambang. Skripsi, Program Pasca Sarjana Teknik Pertambangan, UIN Syarif Hidayatullah, Jakarta

[8.] Wismayanti, M. D., Wijaya, R. A. E. and Sidiq, H. 2020, Evaluasi Kinerja Ala Gali Muat Dan Alat Angkut Terhadap Biaya Operasional Pada Penambangan Bijih Emas Tambang Terbuka Di Kabupaten Bayuwangi, Jurnal Mining Insight, vol 1, hal 79-84. 